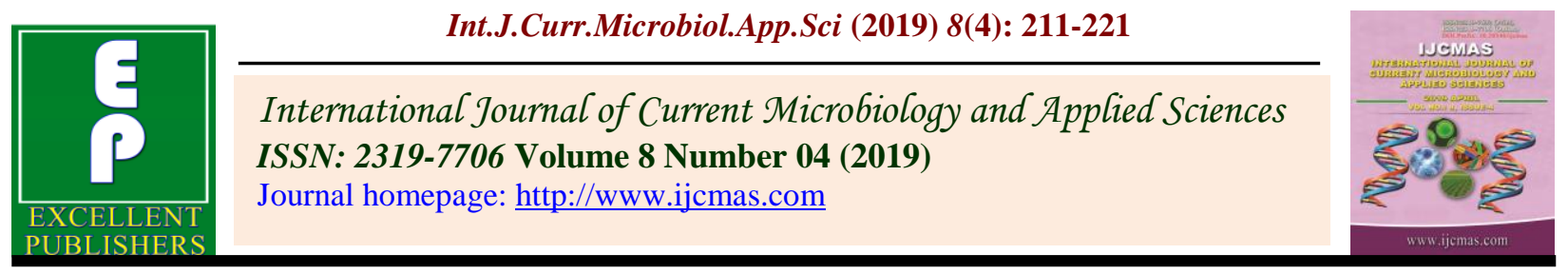

Original Research Article

https://doi.org/10.20546/ijcmas.2019.804.022

\title{
Performance of Baby Corn under Paired Row of Pigeonpea + Baby Corn Inter Cropping System
}

\author{
C.M. Mamathashree*, G.K. Girijesh, M. Dinesh Kumar and N.S. Mavarkar \\ Department of Agronomy, College of Agriculture, University of Agricultural and \\ Horticultural Sciences, Shivamogga, India \\ *Corresponding author
}

\begin{tabular}{|l|}
\hline Ke y w or d s \\
Pigeonpea, Baby \\
corn, Crop \\
geometry
\end{tabular}

A B S T R A C T

A field experiment was carried out to study the effect of planting intercropping system in red sandy loam soil at College of Agriculture Navile, Shivamogga during Kharif of 2016 and 2017. Pigeonpea was taken as base crop and baby corn as inter crop. The experiment with varied planting geometry and nutrient management practices consisted of 12 treatments was laid out in RCBD design replicated thrice. The highest plant height at last harvest was recorded with pigeonpea $(60-120-60 \times 30 \mathrm{~cm})+$ baby corn $(30 \times 30 \mathrm{~cm})$ intercropping $(115.8 \mathrm{~cm})$, Among intercropping treatments pigeonpea $(60-120-60 \times 30$ $\mathrm{cm})+$ baby corn $(60 \times 20 \mathrm{~cm})$ where both the component crops receiving their RDF separately on population basis registered significantly higher total dry matter over other intercropping systems at all growth stages $\left(6.13,52.03\right.$, and $\left.112 \mathrm{~g} \mathrm{plant}^{-1}\right)$ at 20,40 DAS and at harvest. The highest number of babies was counted with sole baby corn sown at 60 $\times 20 \mathrm{~cm}$ apart (7.40) closely followed by sole baby corn of spacing $45 \times 20 \mathrm{~cm}(7.23)$. The highest grain yield of $2494 \mathrm{~kg} \mathrm{ha}^{-1}$ pooled over years was noticed with sole pigeonpea in paired row $60-120-60 \times 30 \mathrm{~cm}$ closely followed by 2454 and $2346 \mathrm{~kg} \mathrm{ha}^{-1}$, It was found that pigeonpea $(60-120-60 \times 30 \mathrm{~cm})+$ baby $\operatorname{corn}(30 \times 30 \mathrm{~cm})$ receiving respective RDF separately by components crops on population basis recorded maximum pigeonpea equivalent yield $\left(4767 \mathrm{~kg} \mathrm{ha}^{-1}\right)$.

\section{Introduction}

The greatest challenge of the $21^{\text {st }}$ century in many developing countries is to produce more and more basic necessities viz., food, fodder, fuel and fiber for ever increasing human and animal population from the limited available land. Food and Agricultural Organization (FAO) estimates revealed that 50 per cent more food grains needs to be produced by
2030 (Abrol et al., 2008) to feed the growing population. This additional production has to come from existing land and water resources. Pulse production in the country is not keeping pace with demand driven by population because of diminishing land holding sizes and competition for land from cereals, commercial crops and horticulture crops. Scope of extending area under pulses as pure stand is blinking. The intercropping system 
besides meeting the varied requirements of the farmers, it harnesses the farm resources efficiently. Development of feasible and economically viable systems largely depends on adoption of proper planting geometry, planting time and selection of compatible crops. Thus, objective of intercropping is now more towards augmenting the total productivity per unit area of land per unit time by growing more than one crop in the same piece of land either simultaneously or sequentially for better utilization of environmental resources (Rajat and Singh, 1979). Morphological features, long duration and elasticity nature of pigeonpea, accommodate more number of short duration crops/vegetables as addition to increase number of products / crops / per unit area in same land in a year as against taking only one crop of maize under rainfed situation which is widely being followed at present in the region.

Importance of baby corn is little known to the Indian farmers in spite of the fact that it fetches very lucrative price in national and international markets. Thailand and China are the world's leading countries in baby corn production. Baby corn cultivation is now picking up in some states of India (Ramachandrappa et al., 2004). Baby corn is the young and unfertilized ear of the corn (Zea mays L.) harvested just before or soon after emergence of silk. Baby corn maize types are medium plant type and provide succulent delicious green ears within 65to 75 days after sowing. The husked young ear in canned or fresh style is more popular vegetable because of its sweetness, flavour, and crispness. It is a highly nutritious vegetable with protein (15-18 \%), sugar (0.016 - $0.020 \%)$, phosphorus $(0.6-0.9 \%)$, potassium (2-3 \%), fibre $(3-5 \%)$, calcium (0.3-0.5\%), ascorbic acid (75-80 mg $\left.100 \mathrm{~g}^{-1}\right)$ as its nutrient composition. In addition, it is a rich source of thiamine, riboflavin and folic acid and low calorie vegetable with high fibre content without cholesterol. Due to its rich nutritive value fetches higher market price resulting into higher income for the growers. Further, it is also free from residual effect of pesticides as it is harvested within a week of tassel emergence and the young cob is wrapped up tightly with husk and well protected from insects and pests (Pradeep et al., 2004). The planting pattern also plays a key factor in exploiting the resources effectively. The technique of paired row planting without reduction in plant population has been developedfor effective and efficient utilization of resources by component crops. There by harness maximum yield advantage from an intercropping system (Waghmore et al., 1982).

\section{Materials and Methods}

Field experiments was conducted to achieve the objectives of the study entitled "Studies on fertilizer management and planting geometry in pigeonpea based bio intensive cropping system during Kharif 2016and 2017 at College of Agriculture, University of Agricultural and Horticultural Sciences (UAHS), Navile, Shivamogga. The soil of experimental field was red sandy loam in texture low in organic carbon $(0.50 \%)$ and available nitrogen $\left(232 \mathrm{~kg} \mathrm{ha}^{-1}\right)$, high in available phosphorus (77.40 $\left.\mathrm{kg} \mathrm{ha}^{-1}\right)$ and medium in available potassium $(193.50 \mathrm{~kg}$ $\left.\mathrm{ha}^{-1}\right)$. The treatments included in the experiment were $\mathrm{T}_{1}$ : Sole pigeonpea $(90 \times 15$ $\mathrm{cm}), \mathrm{T}_{2}$ : Sole pigeonpea $(30 \times 30 \mathrm{~cm}), \mathrm{T}_{3}$ : Sole pigeonpea (Paired row) $(60-120-60 \times 15$ $\mathrm{cm}$ ), $\mathrm{T}_{4}$ : Sole pigeonpea (Paired row) (60$120-60 \times 30 \mathrm{~cm}), \mathrm{T}_{5}: \mathrm{T}_{4}+$ baby corn $(60 \times 20$ $\mathrm{cm}$ ) (RDF separately to both the component crops based on plant population), $\mathrm{T}_{6}: \mathrm{T}_{4}+$ baby corn $(30 \times 30 \mathrm{~cm})(\mathrm{RDF}$ separately to both the component crops based on plant population $), \mathrm{T}_{7}: \mathrm{T}_{4}+$ baby corn $(30 \times 30 \mathrm{~cm})$ (RDF of baby corn as per population applied 
uniformly to both the crops), $\mathrm{T}_{8}$ : $\mathrm{T}_{4}+$ baby corn $(60 \times 20 \mathrm{~cm})(\mathrm{RDF}$ of baby corn as per population applied uniformly to both the crops), $\mathrm{T}_{9}: \mathrm{T}_{4}+$ baby corn $(60 \times 20 \mathrm{~cm})(\mathrm{RDF}$ of pigeonpea as per population applied uniformly to both the crops), $\mathrm{T}_{10}: \mathrm{T}_{4}+$ baby corn $(30 \times 30 \mathrm{~cm})(\mathrm{RDF}$ of pigeon pea as per population applied uniformly to both the crops), $T_{11}$ : Sole baby corn $(60 \times 20 \mathrm{~cm})$, $\mathrm{T}_{12}$ :Sole baby corn $(45 \times 20 \mathrm{~cm})$. The experiment was laid out in randomized block design with three replications.

\section{Plant height}

The plant height of tagged plants was measured from base of the plant to the base of the fully opened top leaf until tassel emergence. After tasseling, the plant height was measured from the base of the plant to base of the flag leaf and average of five plants was represented as plant height and expressed in $\mathrm{cm}$.

\section{Number of leaves}

The total number of green leaves produced plant $^{-1}$ was counted from five randomly selected plants and the average was taken as the number of green leaves plant ${ }^{-1}$

\section{Leaf area index}

Leaf area index is defined as leaf area per unit land area. It was calculated by dividing the leaf area plant ${ }^{-1}$ by the land area occupied by single plant or spacing.

\section{Dry matter production and accumulation in different plant parts}

Three plants from each plot in gross cropped area were collected randomly at 20 and 40 DAS and at harvest separated into leaf, stem and babies and dried in hot air oven at 65 to $70^{\circ} \mathrm{C}$ until constant weight was obtained. Mean was worked out and expressed in $\mathrm{g}$ plant $^{-1}$. Sum of the dry matter accumulation in different plant parts was the total total dry matter $\mathrm{g}$ plant ${ }^{-1}$.

\section{Number of babies harvested plant}

Total number of babies from all the pickings obtained from randomly selected five plants was counted and the average was considered as number of babies per plant.

\section{Weight of dehusked baby}

The babies harvested from sampled five plants of all pickings were dehusked added and average dehusked baby weight was expressed in $\mathrm{g}$.

\section{Dehusked to husked ratio}

It was calculated by using the formula given below

$$
\text { Dehusked to husked } \quad \text { Weight of de husked }
$$

\section{Grain yield}

The grain yield obtained from net plot after threshing winnowing, cleaning, and drying was used to estimate yield ha ${ }^{-1}$ and expressed in $\mathrm{kg} \mathrm{ha}^{-1}$.

\section{Pigeonpea equivalent yield (PEY)}

The pigeonpea equivalent yield of pigeonpea + baby corn intercropping system in experiment - I was calculated by taking into account the grain yield of pigeonpea, yield of babies and green fodder yield of baby corn and the prevailing market prices (Appendix I) Finally pigeonpea equivalent yield was calculated using the formula given below.

$\mathrm{PEY}=\frac{\mathrm{Y}_{\mathrm{bc}} \times \mathrm{P}_{\mathrm{bc}}+\mathrm{Y}_{\mathrm{bg}} \times \mathrm{P}_{\mathrm{bgf}}+\mathrm{Y}_{\mathrm{pp}}}{\mathrm{P}_{\mathrm{pp}}}$ 
Similarly, in experiment II, the pigeonpea equivalent yield was estimated by using the formula given below

$P E Y=\frac{Y_{b c} \times P_{b c}+Y_{b g f} \times P_{b g f}+Y_{r c} \times P_{r c}+Y_{p p}}{P_{p p}}$

$Y_{b c}-$ Yield of baby corn (Baby yield)

$\mathrm{P}_{\mathrm{bc}}$ - Unit price of babies

$\mathrm{Y}_{\mathrm{bgf}^{-}}$Yield of green fodder from baby corn

$\mathrm{P}_{\mathrm{bgf}}-$ Unit price of green fodder

$\mathrm{Y}_{\mathrm{rc}}-\mathrm{Yield}$ of relay intercrops

$\mathrm{P}_{\mathrm{rc}}$ - Unit Price of relay crops

$\mathrm{Y}_{\mathrm{pp}}$ - Yield of pigeonpea

$\mathrm{P}_{\mathrm{bc}}$ - Price of pigeonpea

\section{Results and Discussion}

\section{Growth parameters of baby corn}

The plant height measured at various crop growth stages found significantly varied among treatments at later stages (40 DAS and at harvest). The highest plant height at last harvest was recorded with pigeonpea (60-120$60 \times 30 \mathrm{~cm})+$ baby corn $(30 \times 30 \mathrm{~cm})$ intercropping $(115.8 \mathrm{~cm})$ closely followed by crop geometry of pigeonpea $(60-120-60 \times 30$ $\mathrm{cm})+$ baby corn $(60 \times 20 \mathrm{~cm})$ receiving respective $\mathrm{RDF}$ on population basis by component crops. More plants per unit area in these treatments was the main reason for taller plants due to competition for light and better nutrient supply. This might have also due to legume effect and less weed growth. Similarly, these findings are in line with Bali et al., (2009). Higher plant height of baby corn with crop geometry $45 \times 20 \mathrm{~cm}$ than 60 $\times 20 \mathrm{~cm}$ was attributed to increase in interplant competition.

The leaves per plant recorded as influenced in crop geometry and fertilizer management in pigeonpea + baby corn intercropping system varied significantly at all stages of the crop. The pooled data showed that maximum leaf area index (0.91, 6.01, and 4.72) was estimated with sole baby corn planted at $45 \times$ $20 \mathrm{~cm}$ spacing. It was significantly superior over rest of the treatments at 20 and 40 DAS, whereas, at harvest, it was on par with sole baby corn planted at $60 \times 20 \mathrm{~cm}$ and intercropping system pigeonpea (60-120-60 $\times$ $30 \mathrm{~cm})+$ baby corn $(30 \times 30 \mathrm{~cm})$ where both the component crops received their respective $\mathrm{RDF}$ on population basis. Year wise data almost followed the same trend as that of pooled over years. Among intercropping treatments pigeonpea $(60-120-60 \times 30 \mathrm{~cm})+$ baby corn $(30 \times 30)$ in which both the component crops received respective RDF on population basis recorded maximum LAI of 5.43 and 4.27, respectively, at 40 and at harvest which was significantly superior over others intercropping systems except $\mathrm{T}_{8}$ at 20 DAS and at harvest. Higher LAI, with closer spacing crop is the reflection of proper exploitation of ground area. The next best was $\mathrm{T}_{5}$ pigeonpea $(60-120-60 \times 30 \mathrm{~cm})+$ baby corn $(60 \times 20)$ with application of RDF separately to both the component crops on population basis. Higher LAI was due higher leaf area since; it is a derivative of leaf area. This might be due to wider inter spaces between paired rows which would have helped the intercrops to grow better and making relatively less space available for growth of weeds. Further legumes make part of nitrogen available to baby corn as well. This is in corroboration with findings of Bali reddy et al., (2009) early stages of crop growth.

\section{Total dry matter of baby corn}

Among intercropping treatments pigeonpea $(60-120-60 \times 30 \mathrm{~cm})+$ baby corn $(60 \times 20$ $\mathrm{cm})$ where both the component crops receiving their RDF separately on population basis registered significantly higher total dry matter over other intercropping systems at all growth stages $\left(6.13,52.03\right.$, and 112 g plant $^{-1}$ at 20,40 DAS and at harvest, respectively, 
followed by pigeonpea $(60-120-60 \times 30 \mathrm{~cm})+$ baby corn $(30 \times 30 \mathrm{~cm})$ which are on par. Intercropping treatments where in component crops received their RDF separately on population basis $\left(T_{5}\right.$ and $\left.T_{6}\right)>$ RDF of baby corn uniformly to both the crops $\left(\mathrm{T}_{7}\right.$ and $\left.\mathrm{T}_{8}\right)>$ $\mathrm{RDF}$ of pigeonpea uniformly $\left(\mathrm{T}_{9}\right.$ and $\left.\mathrm{T}_{10}\right)$ are in the order of merit in recording total dry matter. Total dry matter is sum of the dry accumulated in different plant parts. Higher dry matter accumulation in leaves, stem and babies were recorded with sole baby corn treatments $\left(\mathrm{T}_{11}\right.$ and $\left.\mathrm{T}_{12}\right)$ followed by intercropping treatments $T_{5}$ and $T_{6}$ receiving RDF separately on population basis (Table 1). Better dry production in these treatments attributed better nutrient availability as well as other growth resources. The magnitude of dry matter can be more meaningfully interpreted in terms of photosynthetic apparatus (leaf area and leaf area index). The variation among treatments with regard to dry matter accumulation and crop growth rate was due to variation in growth parameters. The total dry matter production curve for baby corn as influenced by planting geometry and fertilizer levels with age of the crops indicate not much variation among treatments at early stages over i.e. $40 \mathrm{DAS}$. As the age advances the total dry matter production per plant was significantly lower under intercropping situations compared to sole crop treatments $\left(T_{11}\right)$. It was due to increase in competition from component pigeonpea for resources. There was a greater difference between sole crop of baby corn and intercropped baby corn.

\section{Yield parameters of baby corn}

\section{Number of babies and baby weight}

The highest number of babies was counted with sole baby corn sown at $60 \times 20 \mathrm{~cm}$ apart (7.40) closely followed by sole baby corn of spacing $45 \times 20 \mathrm{~cm}(7.23)$ which are on par and both the treatments are statistically superior over all intercropping treatments except pigeonpea $(60-120-60 \times 30 \mathrm{~cm})+$ baby corn $(30 \times 30 \mathrm{~cm})$ applying RDF separately to both the component crops with which the treatment sole baby corn $(45 \times 20 \mathrm{~cm})$ was found on par (7.23). The intercropping treatments which are receiving RDF separately to both crops $\left(T_{5}\right.$ and $\left.T_{6}\right)>R D F$ of baby corn uniformly to both the component crops $\left(\mathrm{T}_{7}\right.$ and $\left.\mathrm{T}_{8}\right)>\mathrm{RDF}$ of pigeonpea uniformly to both the crops $\left(\mathrm{T}_{9}\right.$ and $\left.\mathrm{T}_{10}\right)$ are in the order of merit in recording number of babies per plant. The treatments recorded significantly the least number of babies per plant are $T_{9}$ (5.43) and $T_{10}$ (5.44). Almost same trend was noticed both in 2016 and 2017.

\section{Baby weight}

The pooled data on average baby weight indicates the statistically superiority of sole baby corn irrespective of crop geometry with highest mean baby weight being recorded with sole baby corn sown at $60 \times 20 \mathrm{~cm}(7.78$ g plant $^{-1}$ ) closely followed by baby corn of 45 $\times 20 \mathrm{~cm}$ spacing $\left(7.34 \mathrm{~g} \mathrm{plant}^{-1}\right)$ which are significantly differ. Both the sole crop treatments were found significantly superior over all other intercropping treatments. Among intercropping treatments pigeonpea $(60-120-60 \times 30 \mathrm{~cm})+$ baby corn $(60 \times 20$ $\mathrm{cm})$ both the component crops receiving RDF separately. registered the highest mean baby weight of $6.91 \mathrm{~g}$ plant $^{-1}$, which was statistically on par with those intercrop treatments receiving RDF separately to both the crops $\left(\mathrm{T}_{6}\right)$ and RDF of baby corn applied uniformly to both the crops $\left(\mathrm{T}_{7}\right.$ and $\mathrm{T}_{8}$ ). Significantly least baby weight was obtained with treatments which received RDF of pigeonpea on population basis uniformly to both the crops i.e. $\mathrm{T}_{9}\left(5.96 \mathrm{~g} \mathrm{plant}^{-1}\right)$ and $\mathrm{T}_{10}$ $\left(5.84 \mathrm{~g} \mathrm{plant}^{-1}\right)$. In 2016 the highest baby weight per plant was obtained with the sole baby corn of spacing $45 \times 20 \mathrm{~cm}(7.37 \mathrm{~g}$ 
plant $^{-1}$ ) closely followed by sole baby corn spaced at $60 \times 20 \mathrm{~cm}\left(7.36 \mathrm{~g} \mathrm{plant}^{-1}\right)$ and pigeonpea $(60-120-60 \times 30 \mathrm{~cm})+$ baby corn $(60 \times 20 \mathrm{~cm})$ having received RDF to both the crops separately on population basis $(6.77 \mathrm{~g}$ plant $^{-1}$ ) which are on par. Whereas, in 2017 the results are almost in line with pooled data. In both the years the intercropping treatments which received RDF of pigeonpea uniformly by both the component crops have recorded significantly least baby weight per plant $\left(\mathrm{T}_{9}\right.$ and $\mathrm{T}_{10}$ ).yield is a function of yield attributes, the higher values of yield parameters viz., number of babies and baby weight noticed with sole baby corn sown at $60 \times 20 \mathrm{~cm}$ apart (7.40 and $7.78 \mathrm{~g} \mathrm{plant}^{-1}$ ) closely followed by sole baby corn of spaced at $45 \times 20 \mathrm{~cm}(7.23$ and $7.34 \mathrm{~g} \mathrm{plant}^{-1}$ ) apart from differences in population, were the reasons for higher yields. The highest dehusked to husked ratio of babies harvested was found with pigeonpea + baby corn intercropping system and sole baby corn of spacing $45 \times 20 \mathrm{~cm}(0.287)$ for data pooled. This is closely followed sole baby corn spaced at $60 \times 20 \mathrm{~cm}(0.275)$ and intercropping systems pigeonpea (60-120-60 $\times 30 \mathrm{~cm})+$ baby corn $(30 \times 30 \mathrm{~cm})$ receiving RDF separately to both the component crops $(0.270)$.

\section{Baby yield biological yield and green fodder yield}

The mean baby yield obtained by treatment groups as influenced by cropping geometry and fertilizers levels is in the order of merit sole crop $\left(T_{11}\right.$ and $\left.T_{12}\right)>$ intercrop treatments receiving $\mathrm{RDF}$ separately to both the components crops $\left(\mathrm{T}_{5}\right.$ and $\left.\mathrm{T}_{6}\right)>\mathrm{RDF}$ of baby corn uniformly to both the crops ( $\mathrm{T}_{7}$ and $\left.\mathrm{T} 8\right)$ $>$ RDF of pigeonpea ( $\mathrm{T}_{9}$ and $\mathrm{T}_{10}$ ) uniformly to both the component crops. Since, yield is a function of yield attributes, the higher values of yield parameters viz., number of babies and baby weight noticed with sole baby corn sown at $60 \times 20 \mathrm{~cm}$ apart $\left(7.40\right.$ and $\left.7.78 \mathrm{~g} \mathrm{plant}^{-1}\right)$ closely followed by sole baby corn of spaced at $45 \times \quad 20 \mathrm{~cm} \quad(7.23$ and $7.34 \quad \mathrm{~g}$ plant $^{-1}$ ) apart from differences in population, were the reasons for higher yields under sole crop situation. A strong or positive correlation between baby yield ha ${ }^{-1}$ and number of babies per plant ${ }^{-1}(0.942)$ and mean baby weight per $\mathrm{cob}^{-1}$ (0.952) was noticed (Table 2). Higher yield with $45 \times 20 \mathrm{~cm}$ was mainly attributed for higher plant density which seems optimum.

The treatments in which component crops receiving RDF separately $>$ RDF baby corn uniformly to both the crops > RDF of pigeonpea uniformly to both the crops are in the order of merit with respect to baby yield. The variation in yield of baby corn among intercropping treatments was attributed to variation in population and different nutrient management practices (higher nutrients applied and their availability), which influenced greatly the yield components. Higher nutrient availability in treatments $T_{5}$ and $\mathrm{T}_{6}$ attributed higher applied nutrients and improved microbial population (AppendixIX) over other intercropping systems (Bacteria; 256.67 and 272.67, fungi; 170 and 174.17 and actinomycetes; 29.50 and $28.17 \mathrm{cfu} \mathrm{g}^{-1}$ of soil, respectively). The pooled data indicate the statistical superiority of sole baby corn in yielding green fodder $(45 \times 20 \mathrm{~cm})$ over all intercropping treatments as it recorded the highest green fodder yield of 21,088 kg haThis was on par with sole baby corn sown at $60 \times 20 \mathrm{~cm}\left(19,770 \mathrm{~kg} \mathrm{ha}^{-1}\right)$ which is obvious.

Among intercropping treatments, pigeonpea $(60-120-60 \times 30 \mathrm{~cm})+$ baby corn $(30 \times 30$ $\mathrm{cm})$ receiving RDF separately to both the component crops resulted in significantly higher green fodder yield of $18,945 \mathrm{~kg} \mathrm{ha}^{-1}$ over other intercropping treatments. The crop geometry did not influence the green fodder yield. However, the treatment receiving RDF separately to both crops $\left(T_{5}\right.$ and $\left.T_{6}\right)>R D F$ of 
baby corn uniformly to both the crops $\left(\mathrm{T}_{7}\right.$ and $\left.\mathrm{T}_{8}\right)>$ RDF of pigeonpea uniformly to both the crops are in the order of merit statistically. Higher green fodder yield was attributed to plant population (spacing), higher nutrient availability and better exploitation of other production factors with treatments viz., $\mathrm{T}_{6}$ and $\mathrm{T}_{5}$. Further, it is also due higher baby yield as husk also included while estimating the green fodder yield as $3 / 4^{\text {th }}$ of dehusked baby is constituted by husk.

Maximum biological yield of baby corn was realized with sole baby corn spaced at $45 \times 20 \mathrm{~cm} \quad\left(8724 \mathrm{~kg} \quad \mathrm{ha}^{-1}\right)$ which was significantly higher overall intercropping treatments except sole baby corn $(8075 \mathrm{~kg}$ $\mathrm{ha}^{-1}$ ) sown at $60 \times 20 \mathrm{~cm}$ for data pooled over years as the reason known. Among intercropping treatments, significantly higher biological yield of $16,315 \mathrm{~kg} \mathrm{ha}^{-1}$ over rest of the intercropping treatments was obtained with pigeonpea $(60-120-60 \times 30 \mathrm{~cm})+$ baby corn $(30 \times 30 \mathrm{~cm})$. Higher population, higher baby yield and dry biomass are caused for higher biological yield of baby corn at higher plant population.

The intercropping treatments wherein, component crops receiving their RDF separately $\left(\mathrm{T}_{5}\right.$ and $\left.\mathrm{T}_{6}\right)$ and $\mathrm{RDF}$ of baby corn uniformly to both the crops $\left(\mathrm{T}_{7}\right.$ and $\left.\mathrm{T}_{8}\right)$ are statistically on par. Significantly least biological yield of baby corn was recorded with intercropping systems in which RDF of pigeon was applied uniformly both components i.e. $\mathrm{T}_{9}$ and $\mathrm{T}_{10}$ (Table 3 ). This is due less nutrient availability as the recommended quantity of nutrients to pigeonpea is very less (25:50:25 kg ha $\left.{ }^{-1}\right)$ whereas the component baby corn requires almost 6-7 times of nitrogen of that pigeonpea. The highest dehusked to husked ratio of babies harvested was found with pigeonpea + baby corn intercropping system and sole baby corn of spacing $45 \times 20 \mathrm{~cm}$
(0.287) for data pooled. This is closely followed sole baby corn spaced at $60 \times 20 \mathrm{~cm}$ $(0.275)$ and intercropping systems pigeonpea $(60-120-60 \times 30 \mathrm{~cm})+$ baby corn $(30 \times 30$ $\mathrm{cm})$ receiving $\mathrm{RDF}$ separately to both the component crops (0.270).

Higher biological, baby and green fodder yields were positively correlated with yield components in turn yield and yield components are decided by growth parameters. Therefore crop yield depends on the accumulation of photo assimilates during the growing period and the way they are partitioned between desired storage organs of plant and vegetative parts. The sole baby corn irrespective of spacing excelled statistically over all intercropping treatments by recording the highest harvest index of 17.2 and 17.0 per cent with $45 \times 20$ and $60 \times 20 \mathrm{~cm}$, respectively (Table 3). While, no significant differences were found among intercropping treatments with respect to harvest index. However, the intercropping systems in which component crops receiving RDF separately $\left(\mathrm{T}_{5}\right.$ and $\mathrm{T}_{6}$ ) found relatively higher. Thus, higher yield and yield components may be attributed to better crop growth rate, dry matter accumulation and translocation of photosynthates from source to sink.

\section{Pigeonpea yield}

The highest grain yield of $2494 \mathrm{~kg} \mathrm{ha}^{-1}$ pooled over years was noticed with sole pigeonpea in paired row 60-120-60 × $30 \mathrm{~cm}$ closely followed by 2454 and $2346 \mathrm{~kg} \mathrm{ha}^{-1}$, respectively, realized under the intercropping systems pigeonpea $(60-120-60 \times 30 \mathrm{~cm})+$ baby corn $(60 \times 20 \mathrm{~cm})$ and pigeonpea $(60$ $120-60 \times 30 \mathrm{~cm})+$ baby corn $(30 \times 30 \mathrm{~cm})$ wherein, the component crops received their respective RDF separately on population basis were found on par to each other. 
Table.1 Plant height $(\mathrm{cm})$, number of leaves, and leaf area index of baby corn as influenced by planting geometry and fertilizer levels in pigeonpea + baby corn inter cropping system

\begin{tabular}{|c|c|c|c|c|c|c|c|c|c|c|c|c|}
\hline \multirow[t]{2}{*}{ Treatments } & \multicolumn{3}{|c|}{ At harvest } & \multicolumn{3}{|c|}{ At harvest } & \multicolumn{3}{|c|}{ LAI at 40 DAS } & \multicolumn{3}{|c|}{ At harvest } \\
\hline & 2016 & 2017 & $\mathbf{P}$ & 2016 & 2017 & $\mathbf{P}$ & 2016 & 2017 & $\mathbf{P}$ & 2016 & 2017 & $\mathbf{P}$ \\
\hline$T_{1}$ - Sole Pigeonpea $(90 \mathrm{~cm} \times 15 \mathrm{~cm})$ & - & & - & - & - & - & - & - & - & - & - & - \\
\hline$T_{2}$-Sole Pigeonpea $(30 \times 30 \mathrm{~cm})$ & - & - & - & - & - & - & - & - & - & - & - & - \\
\hline$T_{3}$-Sole Pigeonpea (PR: 60-120-60 × $15 \mathrm{~cm}$ ) & - & - & - & - & - & - & - & - & - & - & - & - \\
\hline $\mathrm{T}_{4}$-Sole Pigeonpea (PR:60-120-60 × $30 \mathrm{~cm}$ ) & - & - & - & - & - & - & - & - & - & - & - & - \\
\hline $\begin{array}{l}T_{5}-T_{4}+\text { Baby corn }(60 \times 20 \mathrm{~cm})(\text { RDF separately to } \\
\text { both the component crops based on plant } \\
\text { population) }\end{array}$ & 112.9 & 117.0 & 115.0 & 8.80 & 9.53 & 9.17 & 3.42 & 3.15 & 4.33 & 3.31 & 3.40 & 3.35 \\
\hline $\begin{array}{l}T_{6}-T_{4}+\text { Baby corn }(30 \times 30 \mathrm{~cm})(\text { RDF separately to } \\
\text { both the component crops based on plant population) }\end{array}$ & 114.1 & 117.5 & 115.8 & 9.80 & 9.60 & 9.70 & 3.92 & 3.99 & 5.43 & 4.29 & 4.26 & 4.27 \\
\hline $\begin{array}{l}T_{7}-T_{4}+\text { Baby corn }(60 \times 20 \mathrm{~cm})(\mathrm{RDF} \text { of baby corn } \\
\text { applied uniformly to both the crops })\end{array}$ & 107.5 & 110.3 & 110.3 & 9.33 & 9.00 & 9.17 & 3.08 & 2.61 & 3.71 & 2.93 & 3.05 & 2.99 \\
\hline $\begin{array}{l}T_{8}-T_{4}+\text { Baby corn }(30 \times 30 \mathrm{~cm})(\text { RDF of baby corn } \\
\text { applied uniformly to both the crops })\end{array}$ & 105.5 & 109.8 & 107.6 & 9.47 & 10.00 & 9.73 & 3.83 & 3.13 & 4.70 & 3.68 & 3.79 & 3.74 \\
\hline $\begin{array}{l}T_{9}-T_{4}+\text { Baby corn }(60 \times 20 \mathrm{~cm})(\mathrm{RDF} \text { of pigeonpea } \\
\text { applied uniformly to both the crops })\end{array}$ & 100.2 & 102.3 & 101.2 & 8.07 & 8.13 & 8.10 & 2.45 & 2.17 & 3.04 & 2.64 & 2.49 & 2.56 \\
\hline $\begin{array}{l}\mathrm{T}_{10}-\mathrm{T}_{4}+\text { Baby corn }(30 \times 30 \mathrm{~cm})(\mathrm{RDF} \text { of pigeonpea } \\
\text { applied uniformly to both the crops })\end{array}$ & 92.3 & 102.5 & 97.4 & 8.53 & 8.13 & 8.33 & 2.69 & 2.86 & 3.86 & 3.09 & 3.55 & 3.32 \\
\hline$T_{11}$ - Sole baby corn $(60 \times 20 \mathrm{~cm})$ & 112.5 & 116.7 & 114.6 & 10.80 & 9.33 & 10.07 & 3.88 & 3.65 & 4.97 & 3.81 & 4.25 & 4.03 \\
\hline$T_{12}$-Sole baby corn $(45 \times 20 \mathrm{~cm})$ & 109.3 & 115.5 & 112.4 & 10.60 & 9.07 & 9.83 & 4.34 & 4.46 & 6.01 & 4.54 & 4.90 & 4.72 \\
\hline S. Em \pm & 3.69 & 3.504 & 3.14 & 0.45 & 0.361 & 0.307 & 0.13 & 0.12 & $\begin{array}{c}0.07 \\
\mathbf{0}\end{array}$ & 0.26 & 0.31 & 0.24 \\
\hline CD@5\% & 11.22 & 10.62 & 9.52 & 1.36 & 1.095 & 0.93 & 0.40 & 0.38 & 0.24 & 0.80 & 0.96 & 0.73 \\
\hline
\end{tabular}

RDF: Recommended dose of fertilizers DAS: Days after sowing 
Table.2 Number of babies, mean baby weight (g), dehusked to husked baby ratio as influenced by planting geometry and fertilizer levels under pigeonpea + baby corn intercropping system

\begin{tabular}{|c|c|c|c|c|c|c|c|c|c|}
\hline \multirow[t]{2}{*}{ Treatments } & \multicolumn{3}{|c|}{ Number of babies plant ${ }^{-1}$} & \multicolumn{3}{|c|}{ baby weight (g plant $\left.{ }^{-1}\right)$} & \multicolumn{3}{|c|}{ Dehusked to husked ratio } \\
\hline & 2016 & 2017 & Pooled & 2016 & 2017 & Pooled & 2016 & 2017 & Pooled \\
\hline$T_{1}$ - Sole Pigeonpea $(90 \mathrm{~cm} \times 15 \mathrm{~cm})$ & - & - & - & - & - & - & - & - & - \\
\hline$T_{2}$-Sole Pigeonpea $(30 \times 30 \mathrm{~cm})$ & - & - & - & - & - & - & - & - & - \\
\hline$T_{3}$-Sole Pigeonpea (PR: 60-120-60 × $15 \mathrm{~cm}$ ) & - & - & - & - & - & - & - & - & - \\
\hline $\mathrm{T}_{4}$-Sole Pigeonpea $(\mathrm{PR}: 60-120-60 \times 30 \mathrm{~cm})$ & - & - & - & - & - & - & - & - & - \\
\hline $\begin{array}{l}T_{5}-T_{4}+B a b y \text { corn }(60 \times 20 \mathrm{~cm})(\mathrm{RDF} \\
\text { separately to both the component crops based } \\
\text { on plant population })\end{array}$ & 6.13 & 6.63 & 6.38 & 6.77 & 7.05 & 6.91 & 0.253 & 0.257 & 0.255 \\
\hline $\begin{array}{l}T_{6}-T_{4}+\text { Baby corn }(30 \times 30 \mathrm{~cm})(\text { RDF separately } \\
\text { to both the component crops based on plant } \\
\text { population) }\end{array}$ & 6.50 & 6.90 & 6.70 & 6.61 & 6.90 & 6.78 & 0.280 & 0.260 & 0.270 \\
\hline $\begin{array}{l}\mathrm{T}_{7}-\mathrm{T}_{4}+\text { Baby corn }(60 \times 20 \mathrm{~cm})(\mathrm{RDF} \text { of baby } \\
\text { corn applied uniformly to both the crops })\end{array}$ & 6.00 & 6.40 & 6.20 & 6.06 & 6.83 & 6.44 & 0.270 & 0.233 & 0.252 \\
\hline $\begin{array}{l}T_{8}-T_{4}+\text { Baby corn }(30 \times 30 \mathrm{~cm})(\mathrm{RDF} \text { of baby } \\
\text { corn applied uniformly to both the crops })\end{array}$ & 6.73 & 6.33 & 6.53 & 6.38 & 7.05 & 6.47 & 0.280 & 0.247 & 0.263 \\
\hline $\begin{array}{l}T_{9}-T_{4}+\text { Baby corn }(60 \times 20 \mathrm{~cm})(\mathrm{RDF} \text { of } \\
\text { pigeonpea applied uniformly to both the crops })\end{array}$ & 5.47 & 5.40 & 5.43 & 5.70 & 8.48 & 5.96 & 0.237 & 0.237 & 0.237 \\
\hline $\begin{array}{l}T_{10}-T_{4}+\text { Baby corn }(30 \times 30 \mathrm{~cm})(\mathrm{RDF} \text { of } \\
\text { pigeonpea applied uniformly to both the crops })\end{array}$ & 5.58 & 5.30 & 5.44 & 5.60 & 8.42 & 5.84 & 0.237 & 0.210 & 0.223 \\
\hline$T_{11}-$ Sole baby corn $(60 \times 20 \mathrm{~cm})$ & 7.27 & 7.53 & 7.40 & 7.36 & 11.01 & 7.78 & 0.267 & 0.283 & 0.275 \\
\hline$T_{12}$-Sole baby corn $(45 \times 20 \mathrm{~cm})$ & 7.07 & 7.40 & 7.23 & 7.37 & 10.59 & 7.34 & 0.283 & 0.290 & 0.287 \\
\hline SE.m \pm & 0.27 & 0.19 & 0.20 & 0.24 & 7.36 & 0.12 & 0.00744 & 0.0122 & 0.00784 \\
\hline CD@5\% & 0.82 & 0.57 & 0.620 & 0.75 & 2.23 & 0.37 & 0.023 & 0.037 & 0.024 \\
\hline
\end{tabular}

RDF: Recommended dose of fertilizers DAS: Days after sowing 
Table.3 Baby yield $\left(\mathrm{kg} \mathrm{ha}^{-1}\right)$ green fodder yield, pigeonpea yield and pigeonpea equivalent yield of baby corn as influenced by planting geometry and fertilizer levels in pigeonpea + baby corn intercropping system

\begin{tabular}{|c|c|c|c|c|c|c|c|c|c|c|c|c|}
\hline \multirow[t]{2}{*}{ Treatments } & \multicolumn{3}{|c|}{ Baby yield $\left(\mathrm{kg} \mathrm{ha}^{-1}\right)$} & \multicolumn{3}{|c|}{$\begin{array}{l}\text { Green fodder yield (kg } \\
\left.\text { ha }^{-1}\right)\end{array}$} & \multicolumn{3}{|c|}{$\begin{array}{l}\text { Pigeonpea yield } \\
\quad\left(\mathrm{kg} \mathrm{ha}^{-1}\right)\end{array}$} & \multicolumn{3}{|c|}{$\begin{array}{l}\text { Pigeonpea equivalent } \\
\text { yield }\left(\mathrm{kg} \mathrm{ha}^{-1}\right)\end{array}$} \\
\hline & 2016 & 2017 & Pooled & 2016 & 2017 & Pooled & 2016 & 2017 & Pooled & 2016 & 2017 & Pooled \\
\hline$T_{1}$ - Sole Pigeonpea $(90 \mathrm{~cm} \times 15 \mathrm{~cm})$ & - & - & - & - & - & - & 2133 & 1947 & 2040 & 2134 & 1948 & 2040 \\
\hline$T_{2}$-Sole Pigeonpea $(30 \times 30 \mathrm{~cm})$ & - & - & - & - & - & - & 2286 & 2257 & 2271 & 2286 & 2257 & 2271 \\
\hline $\begin{array}{l}T_{3} \text {-Sole Pigeonpea (PR: 60-120-60 × } 15 \\
\mathrm{am} \text { ) }\end{array}$ & - & - & - & - & - & - & 2218 & 2044 & 2131 & 2218 & 2044 & 2131 \\
\hline $\mathbf{T}_{4}$-Sole Pigeonpea (PR: 60-120-60 × 30 & - & - & - & - & - & - & 2434 & 2555 & 2494 & 2434 & 2555 & 2494 \\
\hline $\begin{array}{l}T_{5}-T_{4}+\text { Baby corn }(60 \times 20 \mathrm{~cm})(\mathrm{RDF} \\
\text { separately to both the component crops } \\
\text { based on plant population) }\end{array}$ & 2749 & 1885 & 2317 & 18,417 & 14,558 & 16,487 & 2419 & 2488 & 2454 & 4284 & 4374 & 4329 \\
\hline $\begin{array}{l}\mathrm{T}_{6}-\mathrm{T}_{4}+\text { Baby corn }(30 \times 30 \mathrm{~cm})(\mathrm{RDF} \\
\text { separately to both the component crops } \\
\text { based on plant population) }\end{array}$ & 3289 & 2610 & 2950 & 21,011 & 16,879 & 18,945 & 2124 & 2568 & 2346 & 4355 & 5180 & 4767 \\
\hline $\begin{array}{l}\mathrm{T}_{7}-\mathrm{T}_{4}+\text { Baby corn }(60 \times 20 \mathrm{~cm})(\mathrm{RDF} \text { of } \\
\text { baby corn applied uniformly to both the } \\
\text { crops) }\end{array}$ & 2629 & 2381 & 2505 & 17,423 & 14,661 & 16,042 & 2019 & 2234 & 2126 & 3802 & 4616 & 4208 \\
\hline $\begin{array}{l}T_{8^{-}} T_{4}+\text { Baby corn }(30 \times 30 \mathrm{~cm})(\mathrm{RDF} \text { of } \\
\text { baby corn applied uniformly to both the } \\
\text { crops })\end{array}$ & 2923 & 2237 & 2580 & 18,245 & 13,940 & 16,093 & 2007 & 2294 & 2151 & 3990 & 4532 & 4260 \\
\hline $\begin{array}{l}T_{9}-T_{4}+\text { Baby corn }(60 \times 20 \mathrm{~cm})(\mathrm{RDF} \text { of } \\
\text { pigeonpea applied uniformly to both the } \\
\text { crops })\end{array}$ & 1588 & 2084 & 1836 & 11,483 & 15,250 & 13,366 & 1736 & 2166 & 1951 & 2814 & 4251 & 3532 \\
\hline $\begin{array}{l}\mathrm{T}_{10}-\mathrm{T}_{4}+\text { Baby corn }(30 \times 30 \mathrm{~cm})(\mathrm{RDF} \text { of } \\
\text { pigeonpea applied uniformly to both the } \\
\text { crops })\end{array}$ & 1661 & 1939 & 1800 & 12,192 & 11,764 & 11,978 & 1696 & 1955 & 1825 & 2823 & 3895 & 3359 \\
\hline$T_{11}-$ Sole baby corn $(60 \times 20 \mathrm{~cm})$ & 4200 & 3449 & 3824 & 25,512 & 14,027 & 19,770 & - & - & - & 2847 & 3449 & 3148 \\
\hline$T_{12}$-Sole baby corn $(45 \times 20 \mathrm{~cm})$ & 4799 & 3580 & 4190 & 27,260 & 14,915 & 21,088 & - & - & - & 3254 & 3581 & 3417 \\
\hline S. Em \pm & 197.20 & 150.70 & 114.519 & 996.1 & 645.8 & 572 & 89.90 & 134 & 85.87 & 150.75 & 172.00 & 117.35 \\
\hline CD@5\% & 598.16 & 457.10 & 347.35 & 3021 & 1959 & 1735 & 267 & 398.43 & 255.14 & 442.17 & 504.49 & 344.20 \\
\hline
\end{tabular}


Higher yield in these treatments was due to better nutrient supply as such they recorded both the component crops received their respective RDF separately on population basis. There was enhancement in the yield level to an extent of 12.2 per cent over sole pigeonpea at $90 \times 15 \mathrm{~cm}$ spacing. This was mainly attributed to higher yield components viz., higher pods plant ${ }^{-1}$, pod weight and grain yield plant $^{-1}$ (227.7, 107.3g and 78.27 g respectively,pooled over years) was recorded with pigeonpea $(60-120-60 \times 30 \mathrm{~cm})+$ baby corn $(60 \times 20 \mathrm{~cm})$, closely followed by pigeonpea $(60-120-60 \times 30 \mathrm{~cm})+$ baby corn $(30 \times 30 \mathrm{~cm})(205.6$ and $103.9,72.10 \mathrm{~g}$, respectively) i.e. $\mathrm{T}_{5}$ and $\mathrm{T}_{6}$ which are statistically on par with each other and found significantly superior over others.

\section{Pigeonpea equivalent yield}

The highest PEY (4767 kg ha ${ }^{-1}$ ) was realized with pigeonpea $(60-120-60 \times 30 \mathrm{~cm})+$ baby corn $(30 \times 30 \mathrm{~cm})$ which was significantly higher than rest of the treatments for pooled data. The next best treatment was pigeonpea $(60-120-60 \times 30 \mathrm{~cm})+$ baby corn $(30 \times 30$ $\mathrm{cm})$ receiving RDF separately by respective component crops (4328 kg ha $\left.{ }^{-1}\right)$. This was on par with those intercropping treatments irrespective of crop geometry where in, component crops receiving RDF of baby corn uniformly $\left(\mathrm{T}_{7}\right.$ and $\left.\mathrm{T}_{8}\right)$.Whereas, intercropping treatments receiving $\mathrm{RDF}$ of pigeonpea uniformly by component crops ( $\mathrm{T}_{9}$ and $\left.\mathrm{T}_{10}\right)$ recorded significantly least PEY compare to other intercropping treatments and sole crop of baby corn found statistically superior over sole pigeonpea treatments. Year wise data indicate the similarity between 2016 and data pooled over years, while, in 2017 , treatments $\mathrm{T}_{6}>\mathrm{T}_{7}>\mathrm{T}_{5}$ are in order of merit.

\section{References}

Abrol, Vikas, Sharma, Peeyush Kumar, Ravindra and Singh, A. K., 2008, Conservation tillage in dryland agriculture-An overview. Indian Fmg., 58(8): 29-32.

Bali, Reddy, V., Bindu, G., Chenga, V., Gurava, K., Chandra, M. and Sekhar., 2009, Intercropping of baby corn (Zea mays L.) with legumes and cover crops. Agric. Sci. Digest., 29(4): 260-263.

Pradeep, K., Yogesh, K. and Akhilesh, S., 2004, Baby corn - A potential crop, Intensive Agric., 23 3-9.

Rajat, D. and Singh, S. P., 1979, Management practices for intercropping systems. Int. Workshop Intercropping, ICRISAT, Hyderabad, India, 17-24.

Ramachandrappa, B. K., Nanjappa, H. V., Thimmegowda, M. N. and Soumya, T. M., 2004, Production management of profitable baby corn cultivation. Indian Fmg., 27(2): 3-7.

Rao, M. R. and Willey, R. W., 1980, Evaluation of yield stability in intercropping studies on sorghum / pigeonpea. Exp. Agric., 16: 105-107.

Waghmore, A.B. and Singh, S.P., 1982, Effect of planting pattern on performance of maize + soyabean intercropping system. Indian J. Agron., 27: 243-246.

\section{How to cite this article:}

Mamathashree, C.M., G.K. Girijesh, M. Dinesh Kumar and Mavarkar, N.S. 2019. Performance of Baby Corn under Paired Row of Pigeonpea + Baby Corn Inter Cropping System. Int.J.Curr.Microbiol.App.Sci. 8(04): 211-221. doi: https://doi.org/10.20546/ijcmas.2019.804.022 